\title{
ФИЗИОЛОГО-БИОХИМИЧЕСКИЕ ХАРАКТЕРИСТИКИ МИКРОПОБЕГОВ ЧАЯ (Camellia sinensis L.) В УСЛОВИЯХ in vitro: НОРМА, ОСМОТИЧЕСКИЙ СТРЕСС, ВЛИЯНИЕ КАЛЬЦИЯ*
}

\author{
Л.С. МАЛЮКОВА 1 $₫$, Т.Л. НЕЧАЕВА², М.Ю. ЗУБОВА², М.В. ГВАСАЛИЯ1, \\ Н.Г. КОНИНСКАЯ 1 , Н.В. ЗАГОСКИНА ${ }^{2}$
}

К важным факторам, определяющим продуктивность растений, относится их устойчивость к стрессовым воздействиям, в том числе к засухе, гипотермии, минеральной недостаточности и засолению. Решению этих проблем, актуальных в связи со всеобеей аридизацией климата, посвящена серия исследований на различных сельскохозяйственных культурах (J.K. Zhu, 2016; E. FletaSoriano, S. Munné-Bosch, 2016), в том числе на чаe (Camellia sinensis L.) (T.K. Maritim с coaвт., 2015; Л.С. Самарина с соавт., 2019). При достаточно детальном изучении физиолого-биохимических и молекулярных механизмов устойчивости чая к засухе практически не охвачена тема их экзогенной регуляции на основе использования химических и биологических веществ. При этом на многих культурах показана важная роль ионов кальция $\left(\mathrm{Ca}^{2+}\right)$ в распознавании клеткой внешнего стрессорного воздействия и запуске системы трансдукции ответного сигнала (М.C. Kim, 2009; Е.Г Рихванов с соавт., 2014). При исследовании этих аспектов достаточно часто в качестве «моделей засухи» используют агаризованные питательные среды с добавлением в них осмотически активных веществ (R.M. Pérez-Clemente с соавт., 2012; M.K. Rai с соавт., 2011) и модельные биосистемы (микропобеги и ткани in vitro), позволяющие раскрыть клеточные механизмы адаптации. Однако в отношении растений чая число подобных исследований невелико (Л.С. Самарина с соавт., 2018; М.В. Гвасалия с соавт., 2019), и они направлены на расшифровку биохимических и молекулярных ответов растений на стрессы. В настоящем сообщении мы впервые на основе отечественных методик получения микропобегов чая в культуре in vitro (М.В. Гвасалия, 2013) и протоколов моделирования осмотического стресса исследовали роль кальция в адаптации растений к стрессовым условиям, вызванным длительным культивированием и осмотическим стрессом, а также продемонстрировали перспективу изучения роли экзогенных индукторов в повышении устойчивости растений на такого рода «моделях засухи». Целью работы было выявление особенностей функционального состояния культивируемых in vitro микропобегов чая, выращиваемых в оптимальных условиях и при моделировании слабого осмотического стресса, обусловленного действием маннита, на фоне разных концентраций кальция $\left(\mathrm{Ca}^{2+}\right)$ в питательной среде. Оценивали морфофизиологическое состояние листьев, их оводненность, проницаемость мембран растительных клеток, содержание малонового диальдегида, пролина и фотосинтетических пигментов. Установлено, что при повышении концентрации Са ${ }^{2+}$ в питательной среде (с 440 до 880 мг/л) при длительном культивировании микропобегов чая in vitro (4 мес) происходит замедление формирования и развития их листьев, а также достоверное снижение содержания малонового диальдегида и проницаемости мембран растительных клеток (в среднем на $50 \%$, p $\leq 0,05$ ), свидетельствующее о менее выраженном развитии процессов липопероксидации. Добавление в питательную среду маннита (40 г/л) снижало оводненность побегов (в среднем на $2 \%, \mathbf{p} \leq \mathbf{0 , 0 5}$ ), формируя тем самым незначительный осмотический стресс, что приводило к накоплению пролина (увеличение на 30-40 \%, p $\leq \mathbf{0 , 0 5}$ ), а также к структурно-функциональной перестройке фотосинтетического аппарата (уменьшение количества фотосинтетических пигментов в среднем на 35-40 \%). При этом отмечали достоверное снижение содержания малонового альдегида (на $50-70 \%, \mathbf{p} \leq \mathbf{0 , 0 5})$ и интенсивности выхода электролитов из тканей листьев (в среднем на $50 \%$, p $\leq 0,05$ ), что указывало на менее выраженный окислительный стресс в сравнении с контролем (без добавления маннита). Повышение концентрации Са ${ }^{2+}$ в питательной среде (с 440 до 880 мг/л) (на фоне добавления маннита) не оказывало достоверного влияния на оводненность тканей и структуру фотосинтетического аппарата (содержание и соотношение хлорофиллов/каротиноидов). Незначительное воздействие кальция (на фоне маннита) проявилось в достоверном уменьшении содержания малонового диальдегида на 20 мкмоль/г сухой массы. Следовательно, добавление в питательную среду повышенной концентрации кальция (660-880 мг/л) обеспечивает улучшение функционального состояния длительно культивируемых микропобегов чая in vitro $(4 \mathrm{mec)}$ за счет снижения активности липопероксидации в мембранах и повышения их стабильности. Выявленные закономерности доказывают положительную роль ионов кальция в снижении комбинированного окислительного стресса, вызванного длительным культивированием растений in vitro в сочетании с осмотическим стрессом.

\footnotetext{
* Исследования выполнены за счет средств гранта РФФИ и Администрации Краснодарского края № 19416-230049, а также при финансовой поддержке Минобрнауки РФ в рамках тем государственного задания ФИЦ СНЦ РАН № 0683-2019-0003 и Института физиологии растений им. К.А. Тимирязева РАН № AАААA-19-11904189005-8.
} 
Ключевые слова: чай, Camellia sinensis L., микропобеги in vitro, кальций, маннит, осмотический стресс, пигменты, пролин, малоновый диальдегид.

Важный фактор, определяющий продуктивность растений, - их устойчивость к стрессовым воздействиям $(1,2)$. К ним относится осмотический стресс, обусловленный действием засухи, гипотермии, засоления, который приводит к обезвоживанию тканей и даже гибели растения $(3,4)$. Воздействие стрессоров прослеживается по комплексу физиолого-биохимических и молекулярных процессов, к числу которых относится рост, оводненность и водный потенциал листьев, ферментативная активность, метаболомный профиль, экспрессия генов $(1,5,6)$.

Особую функцию в поддержании устойчивости растений к действию неблагоприятных факторов среды выполняет кальций $\left(\mathrm{Ca}^{2+}\right)$ (7, 8). Coгласно данным литературы, изменение его концентрации в цитозоле представляет собой первый этап в распознавании клеткой внешнего воздействия и запуске системы трансдукции сигнала для ответной реакции $(7,9,10)$. Важную группу сенсоров, вовлеченных в каскад кальциевых ионных сигналов в клетках высших растений, составляют Са-зависимые протеинкиназы (11, 12). При действии кальция отмечаются изменения в росте, фотосинтезе и водно-воздушном режиме растений, работе устьиц, а также накоплении белков стресса $(7,13)$. За счет индукции антиоксидантной системы снижается степень окислительных повреждений $(14,15)$.

Растения чая (Camellia sinensis L.), которые относятся к важным культурам промышленного использования, возделываются в регионах мира, подверженных засухе (16-18). По данным ряда исследователей $(9,16,18)$, в том числе и авторов (17), гидротермический стресс приводит к потере более $50 \%$ урожая чая при богарном возделывании. Прогрессирующая аридизация климата актуализирует задачу повышения устойчивости растений к засухе. В этой связи большое внимание в исследованиях по культуре чая уделяется изучению механизмов его устойчивости к засухе, поиску наиболее информативных маркеров засухоустойчивости, а также созданию новых устойчивых сортов $(4,9,15)$. При этом практически не охвачены вопросы углубленного понимания метаболизма молодых побегов чая при экзогенном воздействии ряда биогенных элементов и других веществ. В то же время эти аспекты широко исследуются на других культурах, где в качестве «моделей засухи» используют агаризованные питательные среды с добавлением в них осмотически активных веществ (19-21). Это позволяет эффективно контролировать величину водного потенциала, что существенно для обеспечения высокой точности, воспроизводимости и сравнительной оценки различных экспериментов (22).

Культивируемые в условиях in vitro ткани и микропобеги растений представляют собой информативные модельные системы, позволяющие изучать метаболические процессы и ответные клеточные реакции на стрессовые воздействия, включая физиологические и биохимические изменения. Такой подход использовался для выделения устойчивых генотипов картофеля (23), чины посевной (24), огурца (25), фасоли (26) в условиях осмотического стресса (засухи).

Однако в отношении растений чая число подобных исследовании невелико $(27,28)$, и они направлены преимущественно на расшифровку биохимических и молекулярных ответов на действие засухи и получение новых знаний о вызываемых ею изменениях в протеоме и метаболоме. В настоящем сообщении мы впервые установили роль кальция в адаптации микропобегов чая к стрессу, вызванному длительным культивированием в условиях in vitro в сочетании с осмотическим стрессом, а также проде- 
монстрировали перспективу изучения роли экзогенных индукторов в устойчивости растений на такого рода «моделях засухи», созданных на основе агаризованных питательных средах с добавлением в них маннита.

Целью работы было выявление особенностей функционального состояния культивируемых in vitro микропобегов чая, выращиваемых в оптимальных условиях и при моделировании слабого осмотического стресса, обусловленного действием маннита, на фоне разных концентраций кальция $\left(\mathrm{Ca}^{2+}\right)$ в питательной среде.

Meтодика. Микропобеги местной популяции растений чая (Camellia sinensis L.) выращивали in vitro на питательной среде Мурасиге-Скуга, coдержащей 6-бензиламинопурин (БАП, 6 мг/л), 1-нафталинуксусную кислоту (НУК, 1 мг/л), гибберелловую кислоту (ГК, 2 мг/л) (29). При изучении устойчивости микропобегов чая к $\mathrm{Ca}^{2+}$ в питательную среду, содержащую или не содержащую маннит (40 г/л), вносили различные концентрации $\mathrm{CaCl}_{2}$. Дизайн эксперимента включал следующие варианты: 1 - основная питательная среда с $\mathrm{CaCl}_{2}$ (440 мг/л, контроль); 2 - основная питательная среда с $\mathrm{CaCl}_{2}$ (880 мг/л); 3-5 - основная питательная среда с маннитом (40 г/л) и $\mathrm{CaCl}_{2}$ (соответственно 440, 660 и 880 мг/л). В каждом варианте было по 10-15 микропобегов, которые культивировали в течение 4 мес в факторостатной комнате, где соблюдали следующие условия: фотопериод $16 / 8$ ч, температурный режим $25 \pm 1,0{ }^{\circ} \mathrm{C}$, влажность $70 \%$, освещенность 3000 лк (лампы L 36 W/765, «OSRAM GmbH», Германия). Для анализа использовали листья микропобегов.

Для определения оводненности растительный материал высушивали в термостате (BD-115, «Binder $\mathrm{GmbH»,} \mathrm{Германия)} \mathrm{при} 70{ }^{\circ} \mathrm{C}$ до постоянной массы (30).

При оценке стабильности клеточных мембран навеску листьев (50 мг) помещали в деионизированную воду (50 мл). Электропроводность измеряли портативным кондуктометром ST300C, датчик STCON3 (с поверкой) («OHAUS Corporation», США). Измерения проводили через 0; 60 и 120 мин после погружения листьев, а также после 60 мин кипячения растительной пробы. Относительную электропроводность инкубационного раствора рассчитывали по формуле: $\mathrm{REC}=\mathrm{L}_{1} / \mathrm{L}_{2} \times 100 \%$, где $\mathrm{L}_{1}-$ электропроводность через 0 мин, L2 - электропроводность в остывшем растворе после кипячения на водяной бане 1 ч при $100{ }^{\circ} \mathrm{C}(31)$.

Перекисное окисление липидов (ПОЛ) определяли по содержанию малонового диальдегида (МДА) (32). Листья микропобегов чая гомогенизировали в $0,1 \mathrm{M}$ Трис-HCl буфере $(\mathrm{pH} 7,5)$ с $0,35 \mathrm{M} \mathrm{NaCl}$, после чего добавляли $0,5 \%$ раствор тиобарбитуровой кислоты в $20 \%$ водном растворе трихлоруксусной кислоты. Реакционную смесь инкубировали в течение 30 мин на кипящей водяной бане (WB-4MS, «BioSan», Латвия), охлаждали и измеряли оптическую плотность надосадочной жидкости (спектрофотометр СФ46, «ЛОМО», Россия) при $\lambda=532$ нм.

Пигменты экстрагировали из листьев микропобегов чая 96 \% этанолом (32). В надосадочной жидкости, полученной после центрифугирования гомогената (13000 об/мин, 5 мин) спектрофотометрически (СФ-46, «ЛОMO», Россия) определяли количество хлорофилла а (Chla) и хлорофилла b (Chlb) (соответственно $\lambda=665$ нм и $\lambda=649$ нм), а также каротиноидов (Car) $(\lambda=440$ нм). Содержание всех пигментов рассчитывали стандартным методом (33).

Пролин экстрагировали из листьев микропобегов чая стандартным методом и определяли его содержание при $\lambda=520$ нм на приборе УСФ-01 
(«ВНИИИОФИ», Россия), используя нингидриновый реактив (27).

Все определения проводили в трех биологических и трех аналитических повторностях. Статистическую обработку полученных данных осуществляли с помощью программ Microsoft Excel 2010 и SigmaPlot 12.2 (http://www.sigmaplot.co.uk). В таблице и на рисунках представлены средние арифметические значения определений $(M)$ и их стандартные ошибки $( \pm \mathrm{SEM})$. Достоверность различий средних оценивали по $t$-критерию Стьюдента; значения, помеченные разными латинскими буквами, различаются при $\mathrm{p} \leq 0,05$.

Результаты. Известно, что маннит in vitro вызывает осмотический стресс $(27,34)$. В наших опытах микропобеги чая, выращиваемые в течение $4 \mathrm{мec}$ in vitro, были невысокими, что отмечалось и ранее (27). Для них было характерно формирование ярко-зеленых листьев (рис. 1). При высоком содержании $\mathrm{Ca}^{2+}$ в основной питательной среде, которое в 2 раза превышало норму (соответственно 880 и 440 мг/л $\mathrm{CaCl}_{2}$ ), четко проявлялось уменьшение их размера (см. рис. 1, А). Следовательно, повышение его концентрации замедляло формирование и развитие листьев у микропобегов чая. Эта тенденция сохранялась и в условиях осмотического стресса - чем выше была концентрация $\mathrm{Ca}^{2+}$ в среде, тем меньше был размер листьев (см. рис. 1, Б). При этом они были хорошо развиты, то есть ярких проявлений стрессовых реакций мы не наблюдали, что может служить доказательством защитного действия $\mathrm{Ca}^{2+}$, как это отмечалось и в других исследованиях, например у картофеля (23). Отметим, что в доступной литературе мы не обнаружили сообщений о моделировании засухи у чая в условиях in vitro, кроме наших работ.
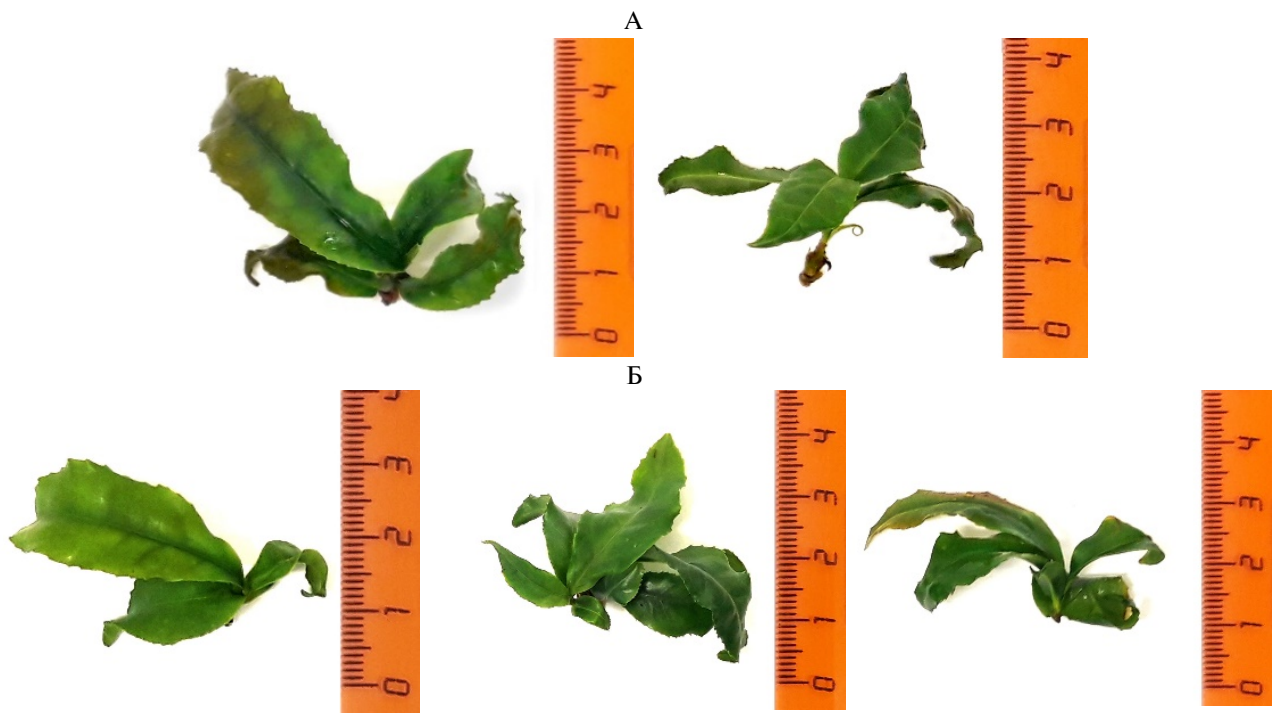

Рис. 1. Микропобеги чая (Camellia sinensis L.), выращенные in vitro на питательной среде с разными концентрациями $\mathrm{CaCl} 2$ в отсутствие (А) или в присутствии (Б) осмотика (маннит, 40 г/л): верхний ряд - 400 мг/л и 800 мг/л, нижний ряд - слева направо 400 мг/л, 600 мг/л и 800 мг/л.

Важный показатель физиологического состояния растения, особенно в условиях засухи, - содержание воды в клетках (19). Наше исследование показало, что оводненность листьев микропобегов чая, выращиваемых на основной питательной среде, не зависела от действующей концентрации $\mathrm{Ca}^{2+}$ и была практически равной в обоих вариантах (табл. 1).

В присутствии маннита оводненность незначительно, но достоверно снижалась (на $2 \%, \mathrm{p} \leq 0,05$ ), и этот эффект не зависел от количества $\mathrm{CaCl}_{2}$ 
в среде. Исходя из этого можно предположить, что $\mathrm{Ca}^{2+}$ способствовал поддержанию водного гомеостаза листьев in vitro у микропобегов чая, культивируемых в условиях осмотического стресса, и этот эффект был практически равным при всех исследованных концентрациях (от 440 до 880 мг/л). Имеются сообщения, что $\mathrm{Ca}^{2+}$ участвует в регуляции реакции растений на неблагоприятное действие засухи (35). У проростков Vernicia fordii Hemsley и Hordeum vulgare L. после обработки этим макроэлементом содержание воды в листьях повышалось, и этот эффект зависел от длительности воздействия и концентрации $\mathrm{Ca}^{2+}$, а также от генотипа растения $(36,37)$.

1. Оводненность листьев микропобегов чая (Camellia sinensis L.), выращенных in vitro, в зависимости от концентрации $\mathrm{CaCl}_{2}$ и присутствия осмотика в питательной среде

\begin{tabular}{l|c|c|c}
\hline Наличие осмотика & Вариант & Концентрация $\mathrm{CaCl} 2$ в среде, мг/л & Оводненность, \% \\
\hline Основная среда & 1 & 400 & $66,22 \pm 1,92^{\mathrm{a}}$ \\
(без маннита) & 2 & 800 & $66,73 \pm 2,28^{\mathrm{a}}$ \\
Основная среда с & 3 & 400 & $64,79 \pm 0,11^{\mathrm{b}}$ \\
маннитом (40 г/л) & 4 & 600 & $64,59 \pm 0,76^{\mathrm{b}}$ \\
& 5 & 800 & $64,40 \pm 1,45^{\mathrm{b}}$ \\
\hline
\end{tabular}

a, b Различия между вариантами, помеченными разными латинскими буквами, статистически значимы при $\mathrm{p} \leq 0,05$.

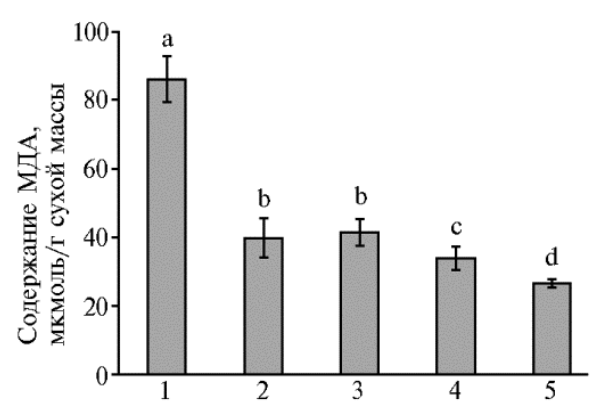

Рис. 2. Содержание малонового диальдегида (МДА)
в листьях микропобегов чая (Camellia sinensis L.),
выращенных in vitro на питательной среде с ра3-
ными концентрациями CaCl2 в отсутствие $(1,2)$ или
в присутствии (3-5) осмотика (маннит, 40 г/л): $1-$
основная среда с 440 мг/л $\mathrm{CaCl} 2$ (контроль); $2-$
основная среда с 880 мг/л $\mathrm{CaCl} 2 ; 3-5-$ среда с
маннитом (40 г/л) и соответственно 440 мг/л,
660 мг/л и 880 мг/л СаCl2. Достоверные разли-
чия средних значений (при р $\leq 0,05)$ отмечены
разными латинскими буквами.

Стрессовые условия, в том числе засуха, часто способствуют образованию активных форм кислорода в клетках растений и усилению окислительных процессов $(1,4,19,35)$. Для их оценки определяют показатели ПОЛ в клетках, о котором судят по количеству МДА $(19,38)$. Более высокое содержание МДА (в среднем почти в 2 раза выше, чем для остальных вариантов) (рис. 2) мы отмечали в листьях микропобегов, выращиваемых на основной среде с низкой концентрацией $\mathrm{Ca}^{2+}\left(440\right.$ мг/л $\left.\mathrm{CaCl}_{2}\right)$. Возможно, такой эффект обусловлен недостатком этого соединения в питательной среде при длительном выращивании микропобегов чая в условиях in vitro. При повышении количества $\mathrm{Ca}^{2+}$ в среде (до 880 мг/л $\mathrm{CaCl}_{2}$ ) содержание МДА в них значительно снижалось и приближалось к значениям в вариантах с действием осмотического стресса в сочетании с различными концентрациями $\mathrm{Ca}^{2+}$. Так, при наличии маннита в питательной среде количество МДА в варианте 3 (440 мг/л $\left.\mathrm{CaCl}_{2}\right)$ было на 51,8 \% ниже, чем в варианте 1 (контроль), на 60,7 \% ниже, чем в варианте 4 (660 мг/л $\left.\mathrm{CaCl}_{2}\right)$, и почти на $70 \%$ ниже, чем в варианте 5 (880 мг/л $\left.\mathrm{CaCl}_{2}\right)$ (при р $\left.\leq 0,05\right)$. Эти результаты позволяют сделать вывод о регуляторном действии не только маннита, но и $\mathrm{Ca}^{2+}$ (особенно высоких его концентраций) на антиоксидантную систему микропобегов чая, что подтверждается данными по снижению уровня ПОЛ в вариантах 2-5 по сравнению с контролем (вариант 1). Как уже отмечалось выше, условия засухи способствуют развитию окислительного стресса, нарушая равновесие между образованием активных форм кислорода и их детоксикацией (39). В этом случае важными вторичными 
мессенджерами в передаче внутриклеточных сигналов в растениях и регулировании окислительных реакций служат ионы $\mathrm{Ca}^{2+}(7,8)$. Показано уменьшение негативных последствий от действия засухи у проростков Helianthus annuus L. после экзогенного применения $\mathrm{Ca}^{2+}(40)$. Данные нашего исследования также свидетельствуют о значительном снижении интенсивности окислительных процессов в клетках микропобегов чая под влиянием $\mathrm{Ca}^{2+}$ в условиях осмотического стресса.

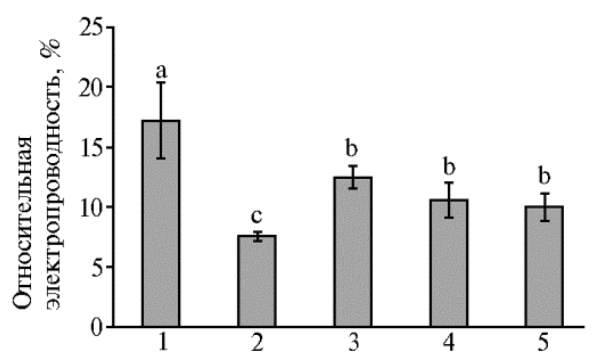

Рис. 3. Относительная электропроводность листьев
микропобегов чая (Camellia sinensis L.), выращен-
ных in vitro на питательной среде с разными кон-
центрациями CaCl2 в отсутствие $(1,2)$ или в при-
сутствии (3-5) осмотика (маннит, 40 г/л): $1-$ ос-
новная среда с $440 \mathrm{Mr} / л \mathrm{CaCl} 2($ контроль); $2-$
основная среда с $880 \mathrm{мг} / л \mathrm{CaCl} 2 ; 3-5-$ среда с
маннитом $(40$ г/л) и соответственно 440 мг/л, 660
мг/л и 880 мг/л СаCl2. Достоверные различия
средних значений (при р $\leq 0,05)$ отмечены раз-
ными латинскими буквами.

Один из начальных этапов реакции клеток растений на стрессоры изменение состояния мембран, показателем которого служит их относительная электропроводность $(7,10)$. Мембранная регуляция клетки, будучи частью всего комплекса систем регуляции в организме, рассматривается как важнейший адаптационный механизм, определяющий сохранение жизнеспособности растения, а проницаемость мембран растительных клеток (интенсивность выхода из тканей электролитов) - как показатель устойчивости растений к стрессу, в том числе осмотическому (41). Для микропобегов чая, выращиваемых на основной среде с $\mathrm{Ca}^{2+}$, по аналогии с содержанием МДА отмечали наиболее высокий выход электролитов (рис. 3). При повышении количества $\mathrm{Ca}^{2+}$ в среде $\left(880 \mathrm{мг} / л \mathrm{CaCl}_{2}\right)$, а также в присутствии маннита выход электролитов снижался в среднем в 1,5-2,0 раза (при $\mathrm{p} \leq 0,05$ ), что свидетельствовало о повышении стабильности клеточных мембран. В условиях осмотического стресса в большей степени это проявлялось при повышенных концентрациях $\mathrm{Ca}^{2+}\left(660\right.$ и 880 мг/л $\left.\mathrm{CaCl}_{2}\right)$, где отмечалось снижение этого показателя (см. рис. 3). Такое снижение указывало на менее выраженное развитие процессов липопероксидации в мембранах этих in vitro культур на фоне действия повышенных концентраций $\mathrm{Ca}^{2+}$, что согласуется с данными литературы $(14,15)$. Закономерности изменения анализируемого показателя напрямую коррелировали с содержанием в листьях МДА, демонстрируя более выраженное развитие процессов липопероксидации в клетках при недостаточном содержании $\mathrm{Ca}^{2+}$ в среде (до 440 мг/л $\mathrm{CaCl}_{2}$ ) в условиях длительного культивирования.

Известно, что при стрессе усиливаются гидролитические процессы, что приводит к накоплению так называемых стрессовых метаболитов, например пролина - низкомолекулярного осмотически активного соединения, способного образовывать гидрофильные коллоиды, что защищает белки от денатурации при различных стрессах (9). Наши исследования показали увеличение содержания свободного пролина в микропобегах чая в условиях осмотического стресса (рис. 4). При этом повышение концентрации $\mathrm{Ca}^{2+}$ в питательной среде до 880 мг/л приводило к достоверному снижению содержание пролина в листьях микропобегов чая. Соотношение абсолютного содержания пролина в микропобегах на средах + маннит/-маннит (после стресса/до стресса), которое отражает интенсивность образования пролина, было наибольшим в варианте с 400 мг/л $\mathrm{CaCl}_{2}$ в питательной среде и составило 1,45 против 1,36 для 880 мг/л $\mathrm{CaCl}_{2}$. 


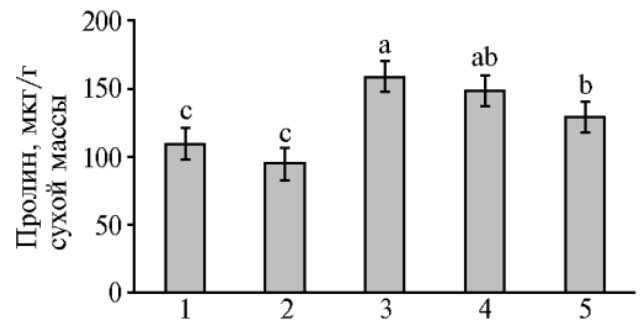

Рис. 4. Содержание пролина в листьях микропобегов чая (Camellia sinensis L.), выращенных in vitro на питательной среде с разными концентрациями $\mathrm{CaCl} 2$ в отсутствие $(1,2)$ или в присутствии (3-5) осмотика (маннит, 40 г/л): 1 основная среда с 440 мг/л $\mathrm{CaCl}_{2}$ (контроль); 2 - основная среда с 880 мг/л $\mathrm{CaCl}_{2} ; 3-5-$ основная среда с маннитом (40 г/л) и соответственно 440 мг/л, 660 мг/л и 880 мг/л $\mathrm{CaCl} 2$. Достоверные различия средних значений (при $\mathrm{p} \leq 0,05)$ отмечены разными латинскими буквами.

2. Содержание (мг/г сухой массы) хлорофилла a (Chla), хлорофилла b (Chlb) и каротиноидов (Car) в листьях микропобегов чая (Camellia sinensis L.), выращенных in vitro, в зависимости от концентрации $\mathrm{CaCl}_{2}$ и присутствия осмотика в питательной среде

\begin{tabular}{|c|c|c|c|c|c|}
\hline Вариант & Chla & Chlb & Car & Chla + Chlb & (Chla + Chlb)/Car \\
\hline \multicolumn{6}{|c|}{ Основная среда без маннита: } \\
\hline 440 мг/л $\mathrm{CaCl}_{2}$ & $3,68 \pm 0,84^{\mathrm{a}}$ & $0,90 \pm 0,30^{\mathrm{a}}$ & $1,74 \pm 0,34^{\mathrm{a}}$ & 4,58 & 2,63 \\
\hline 880 мг/л $\mathrm{CaCl}_{2}$ & $3,91 \pm 0,46^{\mathrm{a}}$ & $0,95 \pm 0,17^{a}$ & $1,82 \pm 0,20^{\mathrm{a}}$ & 4,86 & 2,67 \\
\hline \multicolumn{6}{|c|}{ Основная среда с маннитом (40 г/л): } \\
\hline 440 мг/л $\mathrm{CaCl}_{2}$ & $2,39 \pm 0,32^{\mathrm{b}}$ & $0,73 \pm 0,05^{\mathrm{a}}$ & $1,26 \pm 0,12^{\mathrm{a}}$ & 3,12 & 2,48 \\
\hline 660 мг/л $\mathrm{CaCl}_{2}$ & $1,95 \pm 0,11^{b}$ & $0,54 \pm 0,04 \mathrm{~b}$ & $0,98 \pm 0,04 \mathrm{~b}$ & 2,49 & 2,54 \\
\hline $880 \mathrm{мг/л} \mathrm{CaCl}_{2}$ & $2,07 \pm 0,16^{b}$ & $0,55 \pm 0,04 \mathrm{~b}$ & $1,07 \pm 0,05^{b}$ & 2,62 & 2,45 \\
\hline
\end{tabular}

Влияние осмотиков может вызывать стрессовую реакцию у растений, в том числе приводить к структурно-функциональной перестройке фотосинтетического аппарата и ингибированию фотосинтеза $(42,43)$. Определение содержания фотосинтетических пигментов в листьях микропобегов чая, выращиваемых на основной питательной среде с $\mathrm{Ca}^{2+}$, показало их наибольшие значения, которые были практически равными при обеих его концентрациях (табл. 2). Это может быть следствием структурно-функциональной перестройки фотосинтетического аппарата, а также изменения количества активных форм кислорода, чем и объясняются высокие значения ПОЛ и выхода электролитов (см. рис. 2 и 3) при длительном культивировании микропобегов на питательной среде с низкой концентраций $\mathrm{Ca}^{2+}$ $\left(440\right.$ мг/л $\left.\mathrm{CaCl}_{2}\right)$. Этот аспект представляется нам интересным и будет изучен в дальнейшем.

При выращивании микропобегов на основной среде с разными концентрациями $\mathrm{Ca}^{2+}$ количество Chla в их листьях было наибольшим, тогда как при добавлении маннита оно снижалось у всех вариантов на 35-40 \% $(\mathrm{p} \leq 0,05)$, то есть практически в равной степени (см. табл. 2). Аналогичная тенденция характерна и для содержания Chlb. Количество хлорофилла b было высоким в контрольном варианта (440 мг/л $\left.\mathrm{CaCl}_{2}\right)$, при добавлении к этой среде маннита оно уменьшалось на $20 \%(\mathrm{p} \leq 0,05)$. В случае совместного действия маннита и более высоких концентраций $\mathrm{Ca}^{2+}(660$ и 880 мг/л $\mathrm{CaCl}_{2}$ ) это снижение составило $40 \%$ относительно контроля ( $\left.\mathrm{p} \leq 0,05\right)$. Уменьшение количества хлорофиллов в растительных тканях считается симптомом окислительного стресса и может быть результатом как деградации пигментов, так и структурной реорганизации хлоропластов $(43,44)$.

Пигментная система растений, помимо хлорофиллов, содержит каротиноиды, которые поглощают свет в синей области спектра, защищают фотосинтетический аппарат от фотодеструкции, а также выполняют другие защитные функции (45). Как следует из наших данных, тенденции изменения их количества были в значительной степени аналогичны таковым для хлорофиллов, особенно для Chlb (см. табл. 2). Более высокое содержание 
каротиноидов было характерно для листьев микропобегов чая, выращиваемых на основной среде в присутствии $\mathrm{Ca}^{2+}$, при добавлении к среде осмотика оно снижалось, но лишь в вариантах 4 и 5 (660 и 880 мг/л $\left.\mathrm{CaCl}_{2}\right)$.

Выявленные изменения в содержании пигментов отражают структурно-функциональную реорганизацию фотосинтетического аппарата микропобегов чая при незначительном стрессе, вызванном действием осмотика. Возможно также, что наблюдаемые изменения произошли вследствие роста микропобегов в условиях in vitro, и они в значительной степени обусловлены степенью дифференциации клеточных структур, о чем неоднократно сообщалось $(21,23,29)$.

Таким образом, выращивание микропобегов чая в условиях in vitro на питательной среде Мурасиге-Скуга, содержащей маннит (40 г/л) и 440880 мг/л $\mathrm{CaCl}_{2}$, вызывает изменения их физиолого-биохимических характеристик. Это проявляется в снижении оводненности (на $2 \%, \mathrm{p} \leq 0,05$ ), что свидетельствует о незначительном осмотическом стрессе, в накоплении в листьях свободного пролина, а также в уменьшении количества фотосинтетических пигментов (хлорофилл а, хлорофилл b, каротиноиды). При добавлении в питательную среду маннита и повышении концентрации $\mathrm{Ca}^{2+}$ относительная электропроводность и количество малонового диальдегида в микропобегах уменьшается, что указывает на снижение активности липопероксидации в мембранах. Проведенные исследования раскрывают некоторые клеточные механизмы действия и роль экзогенного $\mathrm{Ca}^{2+}$ в функционировании микропобегов чая при длительном культивировании, в том числе в условиях осмотического стресса. Полученные данные имеют важное значение для депонирования растений чая в биотехнологических коллекциях. Кроме того, они свидетельствуют о значимой роли осмолитов в сохранении и поддержании жизнеспособности растений, особенно в условиях in vitro.

\section{Л И Т Е РАТ У РА}

1. Zhu J.K. Abiotic stress signaling and responses in plants. Cell, 2016, 167(2): 313-324 (doi: 10.1016/j.cell.2016.08.029).

2. Fleta-Soriano E., Munné-Bosch S. Stress memory and the inevitable effects of drought: a physiological perspective. Frontiers in Plant Science, 2016, 7: 143 (doi: 10.3389/fpls.2016.00143).

3. Marcińska I., Czyczyło-Mysza I., Skrzypek E., Filek M., Grzesiak S., Grzesiak M.T., Janowiak F., Hura T., Dziurka M., Dziurka K., Nowakowska A., Quarrie S.A. Impact of osmotic stress on physiological and biochemical characteristics in drought-susceptible and drought-resistant wheat genotypes. Acta Physiologiae Plantarum, 2013, 35(2): 451-461 (doi: 10.1007/s11738012-1088-6).

4. Самарина Л.С., Рындин А.В., Малюкова Л.С., Гвасалия М.В., Маляровская В.И. Физиологические и генетические механизмы ответа чайного растения Camellia sinensis (L.) Kuntze на засуху. Сельскохозяйственная биология, 2019, 54(3): 458-468 (doi: 10.15389/agrobiology.2019.3.458rus).

5. Fayez K.A., Bazaid S.A. Improving drought and salinity tolerance in barley by application of salicylic acid and potassium nitrate. Journal of the Saudi Society of Agricultural Sciences, 2014, 13(1): 45-55 (doi: 10.1016/j.jssas.2013.01.001).

6. Yang Y., Guo Y. Unraveling salt stress signaling in plants. Journal of Integrative Plant Biology, 2018, 60(9): 796-804 (doi: 10.1111/jipb.12689).

7. Медведев С.С. Кальциевая сигнальная система растений. Физиология растений, 2005, 52(2): 282-305.

8. Song W.Y., Zhang Z.B., Shao H.B., Guo X.L., Cao H.X., Zhao H.B., Fu Z.Y., Hu X.J. Relationship between calcium decoding elements and plant abiotic-stress resistance. International Journal of Biological Sciences, 2008, 4(2): 116-125 (doi: 10.7150/ijbs.4.116).

9. Maritim T.K., Kamunya S.M., Mireji P., Wendia C.M., Muoki R.C., Cheruiyot E.K., Wachira F.N. Physiological and biochemical response of tea (Camellia sinensis (L.) O. Kuntze) to water-deficit stress. The Journal of Horticultural Science and Biotechnology, 2015, 90(4): 395400 (doi: 10.1080/14620316.2015.11513200. 0.4236/ajps.2012.34054). 
10. Hetherington A.M., Brownlee C. The generation of $\mathrm{Ca}^{2+}$ signals in plants. Annual Review of Plant Biology, 2004, 55: 401-427 (doi: 10.1146/annurev.arplant.55.031903.141624).

11. Kim M.C. Calcium and calmodulin-mediated regulation of gene expression in plant. Molecular Plant, 2009, 2(1): 13-21 (doi: 10.1093/mp/ssn091).

12. Saidi Y., Finka A., Muriset M., Bromberg Z., Weiss Y. G., Maathuis F.J., Goloubinoff P. The heat shock response in moss plants is regulated by specific calcium-permeable channels in the plasma membrane. Plant Cell, 2009, 21: 2829-2843 (doi: 10.1105/tpc.108.065318).

13. Рихванов Е.Г., Федосеева И.В., Пятрикас Д.В., Боровский Г.Б., Войников В.К. Механизм функционирования кальциевой сигнальной системы у растений при действии теплового стресса. Роль митохондрий в этом процессе. Физиология растений, 2014, 61(2): 155-169 (doi: 10.7868/S0015330314020134).

14. Shu M.Y., Fan M.Q. Effect of osmotic stress and calcium on membrane-lipid peroxidation and the activity of defense enzymes in fir seedling. Forest Research, 2000, 4: 391-396.

15. Upadhyaya H., Panda S.K., Dutta B.K. CaCl2 improves post-drought recovery potential in $\mathrm{Ca}$ mellia sinensis (L) O. Kuntze. Plant Cell Reports, 2011, 30(4): 495-503 (doi: 10.1007/s00299-0100958-x).

16. Bhagat R.M., Baruah R.D., Cacigue S. Climate and tea [Camellia sinensis (L.) O. Kuntze] production with special reference to north eastern India: a review. Journal of Environmental Research and Development, 2010, 4(4): 1017-1028.

17. Малюкова Л.С., Козлова Н.В., Рогожина Е.В., Струкова Д.В., Керимзаде В.В., Великий А.В. Возделывание субтропических культур на Черноморском побережье России: эколого-агрохимические аспекты. Сельскохозяйственная биология, 2014, 3: 24-31 (doi: 10.15389/agrobiology.2014.3.24rus).

18. Baruah R.D., Bhagat R.M. Climate trends of Northeastern India: a longterm pragmatic analysis for tea production. Two and a Bud, 2012, 59(2): 46-49.

19. Osmolovskaya N., Shumilina J., Kim A., Didio A., Grishina T., Bilova T., Frolov A. Methodology of drought stress research: experimental setup and physiological characterization. International Journal of Molecular Sciences, 2018, 19(12): 4089-4114 (doi: 10.3390/ijms19124089).

20. Rai M.K., Kalia R.K., Singh R., Gangola M.P., Dhawan A.K. Developing stress tolerant plants through in vitro selection - an overview of the recent progress. Environmental and Experimental Botany, 2011, 71(1): 89-98 (doi: 10.1016/j.envexpbot.2010.10.021).

21. Pérez-Clemente R.M., Gómez-Cadenas A. In vitro tissue culture, a tool for the study and breeding of plants subjected to abiotic stress conditions. In: Recent advances in plant in vitro culture /A. Leva, L.M.R. Rinaldi (eds.). IntechOpen Limited, London, 2012: 91-108 (doi: 10.5772/50671).

22. Sunaina N.A., Singh N.B. PEG imposed water deficit and physiological alterations in hydroponic cabbage. Iranian Journal of Plant Physiology, 2016, 6(2): 1651-1658.

23. Gelmesa D., Dechassa N., Mohammed W., Gebre E., Monneveux P., Bьndig C., Winkelmann T. In vitro screening of potato genotypes for osmotic stress tolerance. Open Agriculture, 2017, 2(1): 308-316 (doi: 10.1515/opag-2017-0035).

24. Piwowarczyk B., Kami ska I., Rybi ski W. Influence of PEG generated osmotic stress on shoot regeneration and some biochemical parameters in Lathyrus culture. Czech Journal of Genetics and Plant Breeding, 2014, 50(2): 77-83 (doi: 10.17221/110/2013-cjgpb).

25. Abu-Romman S., Suwwan M., Al-Shadiadeh A., Hasan H. Effects of osmotic stress on cucumber (Cucumis sativus 1.) microshoots cultured on proliferation medium. World Applied Sciences Journal, 2012, 20(2): 177-181 (doi: 10.5829/idosi.wasj.2012.20.02.2817).

26. Tejavathi D.H., Devaraj V.R., Murthy S.M., Nijagunaiah R., Shobha K. Effect of PEG induced osmotic stress on proline, protein and relative water content in vitro plants of Macrotyloma uniflorum (Lam.) Verdc. Acta Hortic., 2010, 865: 87-93 (doi: 10.17660/ActaHortic.2010.865.10).

27. Гвасалия М.В., Самарина Л.С., Малюкова Л.С., Маляровская В.И., Рахмангулов Р.С., Конинская Н.Г., Платонова Н.Б., Пащенко О.И. Влияние маннита на рост и физиологические параметры микропобегов чая (Camellia sinensis (L) O. Kuntze) в культуре in vitro. Вестник Мичуринского государственного аграрного университета, 2019, 4(59): 49-53.

28. Гвасалия М.В. Отбор на засухоустойчивость соматических клонов растений чая (Camellia sinensis (L) O. Kuntze) в культуре in vitro. Новые технологии, 2020, 3: 117-124 (doi: 10.24411/2072-0920-2020-10313).

29. Гвасалия М.В. Клональное микроразмножение растений чая (Thea sinensis L.) в культуре in vitro. Садоводство и виноградарство, 2013, 4: 20-22.

30. Зубова М.Ю., Николаева Т.Н., Нечаева Т.Л., Малюкова Л.С., Загоскина Н.В. О содержании пигментов, фенольных соединений и антирадикальной активности молодых побегов чая (Camellia sinensis L.). Химия растительного сырья, 2019, 4: 249-257 (doi: 10.14258/jcprm2019046065).

31. Yoshida K., Matsuo K. A simple method of evaluating the freezing resistance of tea plants ( $\mathrm{Ca}$ mellia sinensis (L.) Kuntze) by measuring electrolyte leakage from low-temperature-treated overwintering buds and leaves. Chagyo Kenkyu Hokoku (Tea Research Journal), 2012, 113: 63-69 (doi: 
10.5979/cha.2012.113-63).

32. Цыпурская Е.В., Казанцева В.В., Фесенко А.Н., Загоскина Н.В. Рост проростков гречихи обыкновенной (Fagopyrum esculentum) и накопление первичных и вторичных метаболитов при различных условиях минерального питания. Сельскохозяйственная биология, 2019, 54(5): 946-957 (doi: 10.15389/agrobiology.2019.5.946rus).

33. Шлык А. А. Определение хлорофиллов и каротиноидов в экстрактах зеленых листьев. В сб.: Биохимические методы в физиологии растений. М., 1971: 154-170.

34. Tholakalabavi A., Zwiazek J.J., Thorpe T.A. Effect of mannitol and glucose-induced osmotic stress on growth, water relations, and solute composition of cell suspension cultures of poplar (Populus deltoides var. occidentalis) in relation to anthocyanin accumulation. In Vitro Cellular \& Developmental Biology-Plant, 1994, 30(3): 164-170 (doi: 10.1007/bf02632208).

35. Xu C., Li X., Zhang L. The effect of calcium chloride on growth, photosynthesis, and antioxidant responses of Zoysia japonica under drought conditions. PloS ONE, 2013, 8(7): e68214 (doi: 10.1371/journal.pone.0068214).

36. Li Z., Tan X.F., Lu K., Liu Z.M., Wu L.L. The effect of $\mathrm{CaCl}_{2}$ on calcium content, photosynthesis, and chlorophyll fluorescence of tung tree seedlings under drought conditions. Photosynthetica, 2017, 55(3): 553-560 (doi: 10.1007/s11099-016-0676-x).

37. Kaczmarek M., Fedorowicz-Stronska O., Głowacka K., Waskiewicz A., Sadowski J. CaCl2 treatment im-proves drought stress tolerance in barley (Hordeum vulgare L.). Acta Physiologiae Plantarum, 2017, 39(1): 41-52 (doi: 10.1007/s11738-016-2336-y).

38. Farmer E.E., Mueller M.J. ROS-mediated lipid peroxidation and RES-activated signaling. Annual Review of Plant Biology, 2013, 64: 429-450 (doi: 10.1146/annurev-arplant-050312-120132).

39. Noctor G., Mhamdi A., Foyer C.H. The roles of reactive oxygen metabolism in drought: not so cut and dried. Plant Physiology, 2014, 164(4): 1636-1648 (doi: 10.1104/pp.113.233478).

40. Madany M., Khalil R. Seed priming with ascorbic acid or calcium chloride mitigates the adverse effects of drought stress in sunflower (Helianthus annuus L.) seedlings. The Egyptian Journal of Experimental Biology (Botany), 2017, 13(1): 119-133 (doi: 10.5455/egyjebb.20170409090612).

41. Demidchik V., Straltsova D., Medvedev S.S., Pozhvanov G.A., Sokolik A., Yurin V. Stressinduced electrolyte leakage: the role of $\mathrm{K}+$-permeable channels and involvement in programmed cell death and metabolic adjustment. Journal of Experimental Botany, 2014, 65(5): 1259-1270 (doi: $10.1093 / \mathrm{jxb} / \mathrm{eru} 004)$.

42. Hu W., Tian S.B., Di Q., Duan S.H., Dai K. Effects of exogenous calcium on mesophyll cell ultrastructure, gas exchange, and photosystem II in tobacco (Nicotiana tabacum Linn.) under drought stress. Photosynthetica, 2018, 56(4): 1204-1211 (doi: 10.1007/s11099-018-0822-8).

43. Софронова В.Е., Чепалов В.А., Дымова О.В., Головко Т.К. Роль пигментной системы вечнозеленого кустарничка Ephedra monosperma в адаптации к климату Центральной Якутии. Физиология растений, 2014, 61(2): 266-274 (doi: 10.7868/s001533031401014x).

44. Fathi A., Tari D.B. Effect of drought stress and its mechanism in plant. International Journal of Life Sciences, 2016, 10(1): 1-6 (doi: 10.3126/ijls.v10i1.14509).

45. Sun T., Yuan H., Cao H., Yazdani M., Tadmor Y., Li L. Carotenoid metabolism in plants: the role of plastids. Molecular Plant, 2018, 11(1): 58-74 (doi: 10.1016/j.molp.2017.09.010).

\footnotetext{
1ФГБУН ФИЦ Субтропический научный иентр РАН,

354002 Россия, г. Сочи, ул. Яна Фабрициуса, 2/28,

Поступила в редакцию
}

e-mail: MalukovaLS@mail.ru $\bowtie$, m.v.gvasaliya@mail.ru, natakoninskaya@mail.ru;

2ФГБУН Институт физиологии растений

им. К.А. Тимирязева РАН,

127276 Россия, г. Москва, ул. Ботаническая, 35,

e-mail: nechaevatatyana.07@yandex.ru, mariaz1809@gmail.com,

nzagoskina@mail.ru $\square$

Sel'skokhozyaistvennaya biologiya [Agricultural Biology], 2020, V. 55, № 5, pp. 970-980

\title{
PHYSIOLOGICAL AND BIOCHEMICAL CHARACTERIZATION OF TEA (Camellia sinensis L.) MICROSHOOTS in vitro: THE NORM, OSMOTIC STRESS, AND EFFECTS OF CALCIUM
}

\author{
L.S. Malyukova ${ }^{\boxplus}$, T.L. Nechaeva², M.Yu. Zubova², M.V. Gvasalia1, N.G. Koninskaya1, \\ N.V. Zagoskina ${ }^{2}$
}

${ }^{1}$ Federal Research Centre the Subtropical Scientific Centre RAS, 2/28, ul. Yana Fabriciusa, Sochi, 354002 Russia, e-mail MalukovaLS@mail.ru (corresponding author $₫$ ), m.v.gvasaliya@mail.ru, natakoninskaya@mail.ru;

${ }^{2}$ Timiryazev Institute of Plant Physiology RAS, 35, ul. Botanicheskaya, Moscow, 127276 Russia, e-mail nechaevatatyana.07@yandex.ru, mariaz1809@gmail.com, nzagoskina@mail.ru (corresponding author $\varangle$ ) 
Malyukova L.S. orcid.org/0000-0003-1531-5745

Nechaeva T.L. orcid.org/0000-0003-3341-4763

Zubova M.Yu. orcid.org/0000-0001-7704-8537

The authors declare no conflict of interests

Supported financially from the Russian Foundation for Basic Research and the Administration of the Krasnodar Territory, grant No. 19-416-230049, and from the Ministry of Education and Science of the Russian Federation within the framework of the state tasks of the FRC SSC RAS No. 0683-2019-0003 and the Timiryazev Institute of Plant Physiology RAS No. AAAA-A-19-11904189005-8

Received June 20, 2020
Gvasalia M.V. orcid.org/0000-0001-7394-4377

Koninskaya N.G. orcid.org/0000-0002-2126-5863

Zagoskina N.V. orcid.org/0000-0002-1457-9450

\section{Abstract}

Stress tolerance is an important trait, that determines the productivity of plants under drought, hypothermia, mineral deficiency, and salinity. Numerous studies of various agricultural crops (J.K. Zhu, 2016; E. Fleta-Soriano, S. Munné-Bosch, 2016), including tea crop (Camellia sinensis L.), were aimed at solving this problem due to the global aridization of the climate. (T.K. Maritim et al., 2015; L.S. Samarina et al., 2019). Along with the sufficiently detailed physiological, biochemical and molecular studies of tea drought tolerance, the exogenous regulation of tolerance by using of chemical and biological substances is still not investigated. In addition, the important role of calcium ions $\left(\mathrm{Ca}^{2+}\right)$ in the cell recognition of an external stressor by the triggering signal transduction has been shown in many crops (M.C. Kim, 2009; E.G. Rikhvanov et al., 2014). In these studies, tissue culture media supplemented with the osmotically active substances (R.M. Pérez-Clemente et al., 2012; M.K. Rai et al., 2011) and artificial biosystems (microshoots and tissues in vitro), are often used as "drought models" to reveal cellular adaptation mechanisms. However, just a few studies were conducted aimed at deciphering the biochemical and molecular responses of tea plant to stress using tissue culture tool (L.S. Samarina et al., 2018; M.V. Gvasaliya et al., 2019). In this article, for the first time, we investigated the role of calcium in plant adaptation to long-term osmotic stress based on earlier published protocols of tea tissue culture (M.V. Gvasaliya, 2013) and osmotic stress induction protocols. We also demonstrated the prospect of studying the role of exogenous inducers in increasing plant tolerance using "drought models". This work aimed to identify the effect of different concentrations of calcium $\left(\mathrm{Ca}^{2+}\right)$ in the culture medium on the functional state of tea microshoots grown under mannitol-induced osmotic stress in vitro comparing with control. The changes in morphophysiological state of the leaves, leaves water content, cells membrane permeability, malondialdehyde, proline, and photosynthetic pigments were analyzed. It was found that increased $\mathrm{Ca}^{2+}$ content in the nutrient medium (from 440 to $880 \mathrm{mg} / \mathrm{l})$ resulted the slower leaves development and significant decrease of malondialdehyde and cell membranes permeability of tea microshoots (by $50 \%, \mathrm{p} \leq 0.05$ ) during the long-term cultivation of tea microshoots in vitro ( 4 months), indicating inhibition of lipid peroxidation processes. The addition of mannitol $(40 \mathrm{~g} / \mathrm{l})$ to the culture medium reduced the water content of the shoots (on average by $2 \%, \mathrm{p} \leq 0.05$ ), thereby forming light osmotic stress, which led to the accumulation of proline (an increase of $30-40 \%, \mathrm{p} \leq 0.05)$, as well as to the structural and functional rearrangement of the photosynthetic apparatus (a decrease in the amount of photosynthetic pigments by an average of 35-40\%). In addition, a significant decrease of malondialdehyde (by 50-70\%, p $\leq 0.05$ ) and the intensity of electrolyte leakage from leaf tissues (on average by $50 \%, \mathrm{p} \leq 0.05$ ) were observed, indicating a less pronounced oxidative stress in comparison with control (without mannitol). An increase in the $\mathrm{Ca}^{2+}$ concentration in the nutrient medium (from 440 to $880 \mathrm{mg} / \mathrm{l}$ ) (in the presence of mannitol) did not significantly affect the water content in the leaves and the photosynthetic apparatus (content and ratio of chlorophylls/carotenoids). An insignificant effect of calcium (in the presence of mannitol) manifested itself in a significant decrease in malondialdehyde by $20 \mu \mathrm{mol} / \mathrm{g}$ dry weight. Consequently, the increased concentration of calcium $(660-880 \mathrm{mg} / \mathrm{l})$ in the nutrient medium provides an improvement in the functional state of long-term cultivated tea microshoots in vitro ( 4 months) by reducing the activity of lipid peroxidation in membranes and increasing their stability. The revealed patterns confirm the positive role of calcium ions in the reduction of combined oxidative stress caused by long-term cultivation of plants in vitro in combination with osmotic stress.

Keywords: tea plants, Camellia sinensis L., in vitro microshoots, calcium, mannitol, osmotic stress, pigments, proline, malondialdehyde. 